\title{
CLASSIFICATION OF SOME LINSEED (Linum usitatissimum L.) GENOTYPES FOR SALINITY TOLERANCE USING GERMINATION, SEEDLING GROWTH, AND ION CONTENT
}

\author{
Mehmet Demir Kaya ${ }^{*}$, Sibel Day ${ }^{2}$, Yakup Cikili ${ }^{3}$, and Neset Arslan²
}

\begin{abstract}
Salinity reduces germination, delays emergence, and inhibits seedling growth of linseed (Linum usitatissimum L.) while some varieties are less affected by salinity than others. In this study, we aimed to determine the effects of $\mathrm{NaCl}$ levels $\left(0,5,10,20\right.$ and $\left.30 \mathrm{dS} \mathrm{m}^{-1}\right)$ on germination and seedling growth of 10 linseed genotypes (lines 87, 89, 104, 114, 193, 194, 209, 215, C-90 and cv. Sar1-85) and to classify the genotypes for salinity tolerance using germination and seedling characteristics. Germination percentage, mean germination time, root and shoot length, seedling fresh and dry weight, $\mathrm{Na}^{+}$ content and $\mathrm{Na}: \mathrm{K}$ ratio of seedlings were investigated. Classification of linseed genotypes for salinity tolerance was done according to (i) combination of Principal Component and Cluster Analysis, (ii) $\mathrm{Na}^{+}$content, and (iii) Na:K ratio of seedling . The results showed that the highest values were obtained from lines 193, 194 and 215 except for mean germination time, while germination percentage was not adversely influenced by $\mathrm{NaCl}$ up to $20 \mathrm{dS} \mathrm{m}^{-1}$. Seedling growth was inhibited at 20 $\mathrm{dS} \mathrm{m} \mathrm{m}^{-1}$ although genotypes exhibited varying responses. $\mathrm{Na}^{+}$content was enhanced by $\mathrm{NaCl}$, but seedling from lines 194 , 193 and 215 had the lowest $\mathrm{Na}^{+}$content at all $\mathrm{NaCl}$ levels. Cluster analysis performed by multiple parameters revealed three groups for salinity tolerance. It was concluded that lines 193, 194, and 215 were tolerant, lines 87, 209, C-90, and cv. Sar1-85 were moderately tolerant and lines 89, 104, and 114 were salt-sensitive genotypes. Classification of genotypes for $\mathrm{Na}^{+}$content and $\mathrm{Na}: \mathrm{K}$ ratio showed similar result for tolerant genotypes while different genotypes for sensitive group were detected.
\end{abstract}

Key words: Linum usitatissimum, $\mathrm{NaCl}$, tolerance, cluster, ion accumulation.

$\mathrm{L}$ inseed (Linum usitatissimum L.) is a cool temperate annual herb with erect stems. Although there are several utilization purposes, it is cultivated commercially for its seed, which is processed into oil and a high protein stock feed after oil extraction (Sankari, 2000; Kurt and Bozkurt, 2006; Berti et al., 2010) and for its fibers, which are made into linen and other cloths (El-Nagdy et al., 2010). In addition, linseed varieties with oils suitable for culinary use are available (Hosseinian et al., 2004).

Linseed has a shallow root system and needs sufficient moisture during the growing season (Hocking et al., 1997). Seedling establishment is generally slow and seedlings have poor competitive ability. Germination and seedling emergence may be influenced by temperature, sowing depth and seedbed conditions like available moisture and salinity (O'Connor and Gusta, 1994; Saeidi and Rowland, 1997; Couture et al., 2004; Kurt

${ }^{1}$ Eskisehir Osmangazi University, Faculty of Agriculture, Department of Field Crops, Eskisehir, Turkey.

"Corresponding author (demirkaya76@hotmail.com).

${ }^{2}$ Ankara University, Faculty of Agriculture, Department of Field Crops, Ankara, Turkey.

${ }^{3}$ Duzce University, Department of Organic Farming, Cilimli Vocational High School, Duzce, Turkey.

Received: 27 April 2011.

Accepted: 20 December 2011. and Bozkurt, 2006). In arid and semi-arid regions where rainfall is insufficient to leach salts out of the root zone, the salinity is a major problem which limits plant growth (Khajeh-Hosseini et al., 2003), since evaporation tends to exceed rainfall (Pessarakli, 1999; Kaya et al., 2003). Salinity leads to delayed germination and emergence, low seedling survival, irregular crop stand and lower yield due to abnormal morphological, physiological and biochemical changes (Ashraf and Fatima, 1994; Munns, 2002; Muhammad and Hussain, 2010).

The main approach of screening the cultivars for salinity tolerance is growing or cultivating them on the salt affected soils. Several researches on the classification of crop plants for salinity have been performed using various criteria such as reduction in plant growth (Bassil and Kaffka, 2002; Akhtar et al., 2003; Hakim et al., 2010), water stress day index (Katerji et al., 2000), biochemical activities (Johnson et al., 2003; Naureen and Naqvi, 2010), ion balance (Ashraf and O'Leary, 1997; Alian et al., 2000; Munns et al., 2006), leaf water potential and stomatal conductance (Ashraf and O'Leary, 1997), and yield reduction (Natarajan et al., 2005). Selection of a salt tolerant genotype based on germination and seedling growth under controlled conditions is simple, quick, precise and not time consuming. Consequently, this research focused on classification of linseed genotypes 
for salt tolerance based on germination and seedling growth along with $\mathrm{Na}^{+}$content and $\mathrm{Na}: \mathrm{K}$ ratio instead of searching a selection criterion.

\section{MATERIALS AND METHODS}

This study was carried out at the Faculty of Agriculture, Ankara University, Turkey. Totally nine linseed genotypes, which lines 87, 89, 104, 114, and C-90 (inbred line from cvs. Sueloef, Verum, Aoyagi, Svetoc and Wiera originated from Germany respectively), lines 193 (K-5843) and 194 (K-6970) from Russia, lines 209 (Kul5215) and 215 (inbred from cv. At125) from Sweden, and one native cultivar Sar1-85 from Turkey improved by single seed selection methods in Ankara University, Turkey, were used as material. Germination and early seedling growth of the genotypes were studied using distilled water (control) and under $\mathrm{NaCl}$ concentrations with the electrical conductivity (EC) values of 5, 10, 20, and $30 \mathrm{dS} \mathrm{m}^{-1}$, respectively.

Four replicates of 50 seeds were germinated between three layered rolled filter paper with $21 \mathrm{~mL}$ of respective test solutions and the papers were replaced every $2 \mathrm{~d}$ to prevent accumulation of salts. The rolled paper with seeds was put into sealed plastic bags to avoid moisture loss. Seeds were allowed to germinate at $20 \pm 1{ }^{\circ} \mathrm{C}$ in the dark. A seed was considered to be germinated when the emerging radicle elongated to $2 \mathrm{~mm}$. Germination percentage was recorded every $24 \mathrm{~h}$ for $10 \mathrm{~d}$. Mean germination time (MGT) was calculated for the speed of germination according to ISTA (2003). Root length, shoot length, seedling fresh and dry weight of 10 seedlings randomly selected from each replicate were measured after the $10^{\text {th }}$ day. Dry weight was measured after drying samples at $70^{\circ} \mathrm{C}$ for $48 \mathrm{~h}$ in an oven. One thousand seed weight of each genotype was determined as an average of $4 \times 100$ seeds.

In order to evaluate the toxic effect of $\mathrm{Na}^{+}$accumulation, all seedlings from each replicate were sampled for mineral analysis. The samples were weighed and separately dried at $70{ }^{\circ} \mathrm{C}$ for $48 \mathrm{~h}$ for mineral analysis $\left(\mathrm{Na}^{+}\right.$and $\mathrm{K}^{+}$ analysis). Sodium and $\mathrm{K}$ analysis were performed using a flame photometric method (Kacar and Inal, 2008).

The experimental design was two factors factorial (10 $\times 5$ ) arranged in a completely randomized design with four replicates and 50 seeds per replicate. The first factor was linseed genotypes and the second was $\mathrm{NaCl}$ levels. Data for germination percentage were subjected to arcsin transformation before ANOVA was made using MSTAT-C program (Michigan State University). The differences between the means were compared using LSD values $(\mathrm{P}<0.05)$. For grouping the genotypes, all measured parameters of the genotypes exposed to various $\mathrm{NaCl}$ levels were considered. Principle Component and Cluster Analysis was performed by classifying the genotypes for salinity tolerance.

\section{RESULTS AND DISCUSSION}

There is a significant difference for one thousand seed weight of linseed genotypes $(\mathrm{P}<0.05)$. Heavier seed weight was measured in lines 193 and 215, followed by line 194, cv. Sar1-85 and line 209 (Figure 1). A significant two way interaction (genotype and $\mathrm{NaCl}$ ) was found $(\mathrm{P}<0.05)$ for all investigated characters. Germination percentage was not significantly reduced

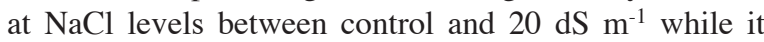
declined considerably at $30 \mathrm{dS} \mathrm{m}^{-1}$. The highest decrease in germination was determined in lines 87, 89, 114 and cv. Sar1-85 while the highest germination percentage $(72.5 \%)$ at $\mathrm{NaCl}$ concentration of $30 \mathrm{dS} \mathrm{m} \mathrm{m}^{-1}$ was detected in line 194 (Table 1). Mean germination time (MGT) was delayed by increasing salinity stress; however, $\mathrm{NaCl}$ level of 20 $\mathrm{dS} \mathrm{m} \mathrm{m}^{-1}$ retarded it much more compared to lower level of $\mathrm{NaCl}$. The MGT was not calculated at $30 \mathrm{dS} \mathrm{m} \mathrm{m}^{-1}$ because of insufficient germination. The fastest germination at $20 \mathrm{dS} \mathrm{m} \mathrm{m}^{-1}$ was recorded in line 104 with $1.73 \mathrm{~d} . \mathrm{NaCl}$ adversely influenced germination percentage, mean time to germination and seedling growth of linseed genotypes, but any inhibitory effects of $\mathrm{NaCl}$ lower than $30 \mathrm{dS} \mathrm{m}^{-1}$ on germination percentage were not determined. The results of this study are in agreement with the observations of Muhammad and Hussain (2010), who observed that $\mathrm{NaCl}$ levels between 0 and $15 \mathrm{dS} \mathrm{m} \mathrm{m}^{-1}$ did not adversely affect germination percentage and the least affected species for decreasing germination percentage was L. usitatissimum . El-Nakhlaway and El-Fawal (1989) reported significantly reduced germination with increasing salinity in Linum. This result could be explained osmotic stress constituted by salt concentrations or specific ion effects which delay or/and inhibit germination as reported by Almansouri et al. (2001), Kaya et al. (2006) and Atak et al. (2006). On the other hand, germination of large or heavy seeded varieties is influenced deeply by the osmotic stress created by salinity (Kaya et al., 2008) while large seeds produced vigorous seedlings compared to small seeds (Soltani et al., 2002). The lower MGT in control $\left(0.0 \mathrm{dS} \mathrm{m} \mathrm{m}^{-1}\right)$ and reduced MGT in heavier seeds compared to light seeded genotypes under $\mathrm{NaCl}$ stress were observed in this study.

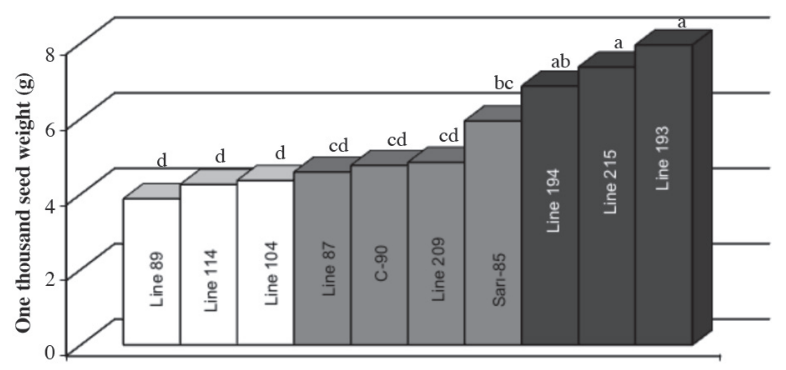

Figure 1. One thousand seed weight of 10 linseed genotypes calculated as an average of $4 \times 100$ seeds. Letters on each bar show significance level of means at $p<0.05$ level. 
Table 1. Germination and seedling characteristics of 10 linseed genotypes used for grouping for salinity tolerance under various NaCl levels.

\begin{tabular}{|c|c|c|c|c|c|c|c|}
\hline Genotype & $\mathrm{NaCl}$ & Germination & MGT & Root length & Shoot length & $\begin{array}{c}\text { Seedling } \\
\text { fresh weight }\end{array}$ & $\begin{array}{c}\text { Seedling } \\
\text { dry weight }\end{array}$ \\
\hline & $\mathrm{dS} \mathrm{m} \mathrm{m}^{-1}$ & $\%$ & $\mathrm{~d}$ & 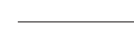 & 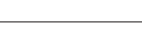 & $\longrightarrow \mathrm{m}$ & -1 \\
\hline & 0 & $99.5 \pm 0.5$ & $1.22 \pm 0.06$ & $2.33 \pm 0.27$ & $7.18 \pm 0.23$ & $48.8 \pm 0.95$ & $2.50 \pm 0.28$ \\
\hline & 5 & $100.0 \pm 0.0$ & $1.10 \pm 0.06$ & $3.86 \pm 0.14$ & $10.93 \pm 0.14$ & $57.0 \pm 1.22$ & $2.75 \pm 0.25$ \\
\hline \multirow[t]{5}{*}{ Line 87} & 10 & $100.0 \pm 0.0$ & $1.21 \pm 0.07$ & $5.07 \pm 0.24$ & $9.70 \pm 0.16$ & $52.8 \pm 0.85$ & $2.50 \pm 0.28$ \\
\hline & 20 & $100.0 \pm 0.0$ & $2.12 \pm 0.03$ & $6.30 \pm 0.52$ & $6.38 \pm 0.19$ & $43.8 \pm 1.25$ & $2.50 \pm 0.28$ \\
\hline & 30 & $3.5 \pm 1.0$ & - & - & - & - & - \\
\hline & 0 & $100.0 \pm 0.0$ & $1.05 \pm 0.01$ & $5.37 \pm 0.22$ & $12.73 \pm 0.79$ & $83.3 \pm 3.59$ & $4.00 \pm 1.15$ \\
\hline & 5 & $99.0 \pm 0.6$ & $1.10 \pm 0.06$ & $5.01 \pm 0.37$ & $15.35 \pm 0.79$ & $89.3 \pm 5.70$ & $3.75 \pm 0.75$ \\
\hline \multirow[t]{5}{*}{ Line 193} & 10 & $100.0 \pm 0.0$ & $1.20 \pm 0.01$ & $6.20 \pm 0.60$ & $15.16 \pm 0.27$ & $91.5 \pm 4.65$ & $4.75 \pm 0.47$ \\
\hline & 20 & $100.0 \pm 0.0$ & $2.07 \pm 0.05$ & $6.08 \pm 0.39$ & $6.98 \pm 0.19$ & $68.8 \pm 2.43$ & $4.75 \pm 0.25$ \\
\hline & 30 & $14.5 \pm 2.7$ & - & - & - & - & - \\
\hline & 0 & $97.0 \pm 1.9$ & $1.47 \pm 0.04$ & $3.16 \pm 0.31$ & $6.49 \pm 0.45$ & $55.3 \pm 2.50$ & $3.25 \pm 0.25$ \\
\hline & 5 & $100.0 \pm 0.0$ & $1.19 \pm 0.02$ & $6.80 \pm 0.41$ & $10.33 \pm 0.12$ & $66.0 \pm 2.17$ & $3.25 \pm 0.25$ \\
\hline \multirow[t]{5}{*}{ Sarı-85 } & 10 & $100.0 \pm 0.0$ & $1.65 \pm 0.08$ & $4.73 \pm 0.34$ & $9.15 \pm 0.28$ & $67.8 \pm 1.65$ & $4.00 \pm 0.41$ \\
\hline & 20 & $99.5 \pm 0.5$ & $2.83 \pm 0.09$ & $6.43 \pm 0.20$ & $2.38 \pm 0.50$ & $44.5 \pm 1.32$ & $5.00 \pm 0.00$ \\
\hline & 30 & $0.0 \pm 0.0$ & - & - & - & - & - \\
\hline & 0 & $100.0 \pm 0.0$ & $1.03 \pm 0.00$ & $4.71 \pm 0.16$ & $14.55 \pm 0.53$ & $77.0 \pm 3.46$ & $4.00 \pm 0.00$ \\
\hline & 5 & $98.0 \pm 1.1$ & $1.01 \pm 0.00$ & $5.21 \pm 0.47$ & $16.12 \pm 0.12$ & $77.8 \pm 3.54$ & $3.75 \pm 0.25$ \\
\hline \multirow[t]{5}{*}{ Line 194} & 10 & $100.0 \pm 0.0$ & $1.07 \pm 0.03$ & $7.75 \pm 1.14$ & $15.28 \pm 0.23$ & $76.8 \pm 1.03$ & $4.25 \pm 0.25$ \\
\hline & 20 & $98.5 \pm 1.5$ & $2.37 \pm 0.03$ & $5.46 \pm 0.24$ & $9.74 \pm 0.39$ & $59.0 \pm 2.34$ & $4.25 \pm 0.47$ \\
\hline & 30 & $72.5 \pm 8.1$ & - & - & - & - & - \\
\hline & 0 & $100.0 \pm 0.0$ & $1.04 \pm 0.02$ & $4.75 \pm 0.08$ & $5.38 \pm 0.15$ & $38.5 \pm 2.06$ & $2.00 \pm 0.00$ \\
\hline & 5 & $100.0 \pm 0.0$ & $1.04 \pm 0.02$ & $4.55 \pm 0.25$ & $10.95 \pm 0.31$ & $53.5 \pm 0.65$ & $2.50 \pm 0.28$ \\
\hline \multirow[t]{5}{*}{ Line 114} & 10 & $100.0 \pm 0.0$ & $1.14 \pm 0.05$ & $4.35 \pm 0.47$ & $9.45 \pm 0.34$ & $45.3 \pm 1.84$ & $2.75 \pm 0.25$ \\
\hline & 20 & $100.0 \pm 0.0$ & $2.61 \pm 0.05$ & $6.40 \pm 0.15$ & $6.28 \pm 0.14$ & $42.0 \pm 1.47$ & $3.25 \pm 0.25$ \\
\hline & 30 & $1.0 \pm 0.5$ & - & - & - & - & - \\
\hline & 0 & $100.0 \pm 0.0$ & $1.02 \pm 0.01$ & $4.87 \pm 0.08$ & $9.05 \pm 0.15$ & $61.5 \pm 0.50$ & $2.75 \pm 0.25$ \\
\hline & 5 & $100.0 \pm 0.0$ & $1.06 \pm 0.02$ & $4.03 \pm 0.36$ & $10.78 \pm 0.19$ & $58.5 \pm 1.19$ & $3.25 \pm 0.25$ \\
\hline \multirow[t]{5}{*}{ Line 209} & 10 & $100.0 \pm 0.0$ & $1.11 \pm 0.04$ & $5.15 \pm 0.77$ & $10.70 \pm 0.31$ & $60.8 \pm 0.85$ & $3.00 \pm 0.00$ \\
\hline & 20 & $100.0 \pm 0.0$ & $2.58 \pm 0.17$ & $7.60 \pm 0.25$ & $6.35 \pm 0.37$ & $48.0 \pm 1.08$ & $3.50 \pm 0.28$ \\
\hline & 30 & $10.0 \pm 0.8$ & - & - & - & - & - \\
\hline & 0 & $100.0 \pm 0.0$ & $1.07 \pm 0.02$ & $2.44 \pm 0.64$ & $7.99 \pm 0.22$ & $72.0 \pm 3.72$ & $5.25 \pm 0.25$ \\
\hline & 5 & $100.0 \pm 0.0$ & $1.06 \pm 0.02$ & $4.28 \pm 0.14$ & $11.80 \pm 0.41$ & $86.8 \pm 3.54$ & $4.25 \pm 0.25$ \\
\hline \multirow[t]{5}{*}{ Line 215} & 10 & $100.0 \pm 0.0$ & $1.10 \pm 0.04$ & $7.25 \pm 0.67$ & $10.70 \pm 0.55$ & $77.3 \pm 2.29$ & $5.25 \pm 0.25$ \\
\hline & 20 & $100.0 \pm 0.0$ & $2.03 \pm 0.04$ & $6.53 \pm 0.17$ & $6.48 \pm 0.24$ & $60.0 \pm 1.73$ & $4.75 \pm 0.47$ \\
\hline & 30 & $37.0 \pm 2.5$ & - & - & - & - & - \\
\hline & 0 & $100.0 \pm 0.0$ & $1.05 \pm 0.03$ & $7.23 \pm 0.41$ & $9.25 \pm 0.23$ & $50.0 \pm 0.91$ & $2.25 \pm 0.25$ \\
\hline & 5 & $100.0 \pm 0.0$ & $1.05 \pm 0.02$ & $3.28 \pm 0.14$ & $11.18 \pm 0.07$ & $53.8 \pm 1.31$ & $1.25 \pm 0.14$ \\
\hline \multirow[t]{5}{*}{ Line 89} & 10 & $100.0 \pm 0.0$ & $1.27 \pm 0.07$ & $5.50 \pm 0.24$ & $12.23 \pm 0.17$ & $58.0 \pm 2.89$ & $2.50 \pm 0.28$ \\
\hline & 20 & $99.0 \pm 1.0$ & $5.19 \pm 0.20$ & $2.56 \pm 0.18$ & $2.44 \pm 0.43$ & $27.8 \pm 2.12$ & $2.25 \pm 0.25$ \\
\hline & 30 & $0.0 \pm 0.0$ & - & - & - & - & - \\
\hline & 0 & $100.0 \pm 0.0$ & $1.03 \pm 0.01$ & $5.06 \pm 0.53$ & $8.19 \pm 0.05$ & $56.8 \pm 1.11$ & $2.75 \pm 0.25$ \\
\hline & 5 & $100.0 \pm 0.0$ & $1.05 \pm 0.01$ & $4.69 \pm 0.65$ & $12.92 \pm 0.16$ & $69.0 \pm 2.48$ & $2.75 \pm 0.25$ \\
\hline \multirow[t]{5}{*}{ C-90 } & 10 & $100.0 \pm 0.0$ & $1.11 \pm 0.02$ & $7.34 \pm 0.18$ & $12.53 \pm 0.36$ & $64.0 \pm 2.00$ & $3.25 \pm 0.25$ \\
\hline & 20 & $99.5 \pm 0.5$ & $2.97 \pm 0.44$ & $3.93 \pm 0.41$ & $5.74 \pm 0.57$ & $46.5 \pm 1.66$ & $2.75 \pm 0.47$ \\
\hline & 30 & $5.5 \pm 1.2$ & - & - & - & - & - \\
\hline & 0 & $100.0 \pm 0.0$ & $1.00 \pm 0.00$ & $4.88 \pm 0.47$ & $9.69 \pm 0.38$ & $47.8 \pm 1.49$ & $2.25 \pm 0.25$ \\
\hline & 5 & $100.0 \pm 0.0$ & $1.01 \pm 0.00$ & $4.54 \pm 0.23$ & $13.38 \pm 1.22$ & $58.5 \pm 1.04$ & $2.25 \pm 0.25$ \\
\hline \multirow[t]{3}{*}{ Line 104} & 10 & $100.0 \pm 0.0$ & $1.07 \pm 0.04$ & $6.41 \pm 0.25$ & $11.55 \pm 0.26$ & $50.3 \pm 1.11$ & $2.75 \pm 0.47$ \\
\hline & 20 & $100.0 \pm 0.0$ & $1.73 \pm 0.09$ & $4.29 \pm 0.40$ & $5.95 \pm 0.21$ & $43.8 \pm 1.70$ & $2.00 \pm 0.40$ \\
\hline & 30 & $9.0 \pm 3.0$ & - & - & - & - & - \\
\hline $\mathrm{LSD}_{\text {int. }}(\mathrm{p}<0.05)$ & & 2.62 & 0.26 & 1.03 & 1.11 & 6.15 & 0.91 \\
\hline
\end{tabular}

Data represent mean \pm standard error (SE) of four replicates.

MGT: Mean germination time.

Increasing $\mathrm{NaCl}$ resulted in increase in root length of almost all of the linseed genotypes up to $20 \mathrm{dS} \mathrm{m}^{-1}$ except for line 89 . None of the genotypes were able to grow roots at $30 \mathrm{dS} \mathrm{m}^{-1}$. Line 209 was superior to the others at $20 \mathrm{dS}$ $\mathrm{m}^{-1}$ and had a root length of $7.65 \mathrm{~cm}$. Greater reduction in shoot length due to $\mathrm{NaCl}$ was very evident at $20 \mathrm{dS} \mathrm{m}^{-1}$ $(\mathrm{P}<0.05)$ with no recorded shoot growth at $30 \mathrm{dS} \mathrm{m}^{-1}$. $\mathrm{NaCl}$ enhanced shoot growth up to $10 \mathrm{dS} \mathrm{m}^{-1}$ while, it was inhibited dramatically at $20 \mathrm{dS} \mathrm{m}^{-1}$. Soltani et al. (2002) observed that root length of chickpea was diminished by increasing $\mathrm{NaCl}$ concentration while large seeds gave vigorous seedling growth compared to small seeds. It is assumed that variation in seed reserve of linseed genotypes we used was responsible for the differences in seedling growth because higher seed weight resulted in higher germination and vigorous seedling growth. Although Diederichsen and Jones-Flory (2005) stated that seed vigor was not correlated with 1000 seed weight of 
linseed cultivars, seed weight would be responsible for seedling growth as supported by Soltani et al. (2002) and Kaya et al. (2008) in chickpea, Kaya and Day (2008) in sunflower, who found relationship between seed weight and seedling growth.

Depending on decrease in shoot and root length, seedling fresh weight gradually declined with the increasing salinity stress. Considering each genotype higher seedling fresh weights were recorded from lines 193, 194, and 215 under salinity stress. Increasing salinity levels did not cause remarkably decreases in seedling dry weight. Although our genotypes showed different responses to each salt level and produced varying levels of dry weight, the highest dry weight in all salinity levels were usually obtained from line 215 . These results were similar to those observed by Chandru et al. (1993) in sunflower (Helianthus annuus L.), Ghorashy et al. (1972) and Kaya et al. (2003) in safflower (Carthamus tinctorius L.), Ashraf and Fatima (1994) in linseed and Saboora and Kiarostami (2006) in wheat (Triticum aestivum L.). In our study, the linseed genotypes we used could keep up with the soil salinity up to $20 \mathrm{dS} \mathrm{m}^{-1}$ during the germination and early growth stages, though, both the germination percentage and seedling growth fell sharply down at higher salinity level of $20 \mathrm{dS} \mathrm{m}^{-1}$.

Seedling samples from 10 linseed genotypes showed that increased levels of $\mathrm{NaCl}$ affected significantly the $\mathrm{Na}^{+}$content of linseed seedlings (Figure 2). Considering linseed genotypes, seedling from lines 193, 215, and 194 had lower $\mathrm{Na}^{+}$content than the others. Linseed genotypes gave different $\mathrm{Na}: \mathrm{K}$ ratio while lower Na:K ratio was recorded in lines 194, 193, 215, C-90, and 104, respectively (Figure 3 ). Reducing cell division and plant growth metabolism induced by accumulation of $\mathrm{Na}^{+}$ion caused changes in ion balances and the imbalance of mineral nutrients resulted in a reduction or an inhibition of plant growth were reported by Mer et al. (2000). $\mathrm{Na}^{+}$content increased with increasing salinity level and peaked at $20 \mathrm{dS} \mathrm{m}^{-1}$. This means that $\mathrm{Na}^{+}$accumulation was harmful because the genotypes with low $\mathrm{Na}^{+}$content like lines 193, 194, and 215, possessed more vigorous seedling growth than the other genotypes. Na:K ratio

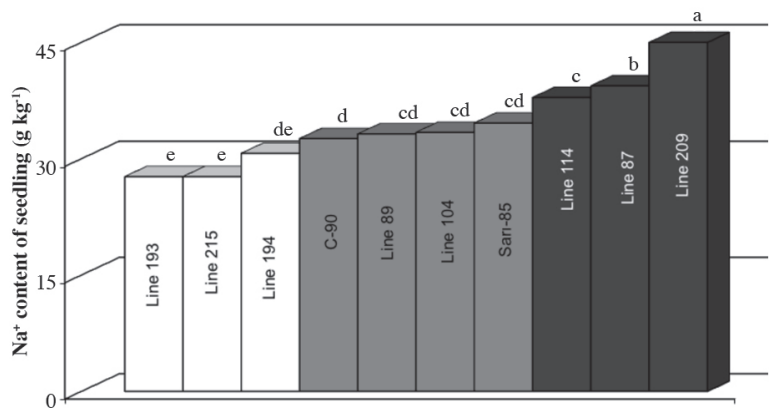

Figure 2. Classification of $\mathbf{1 0}$ linseed genotypes for salinity tolerance using $\mathrm{Na}^{+}$content measured at $10 \mathrm{~d}$ old seedlings. Letters on each bar show significance level of means at $p<0.05$ level.

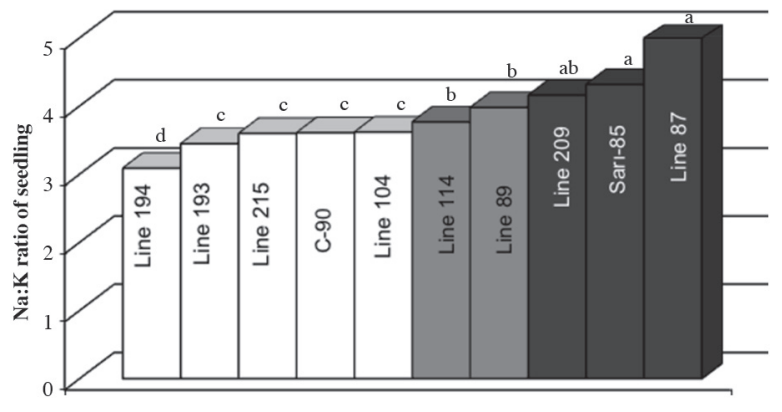

Figure 3. Classification of 10 linseed genotypes for salinity tolerance using $\mathrm{Na}$ K ratio measured at $10 \mathrm{~d}$ old seedlings. Letters on each bar show significance level of means at $p<0.05$ level.

shows ion balance of linseed seedling and an important criteria for seedling survival under $\mathrm{NaCl}$ stress. Increased $\mathrm{NaCl}$ promoted $\mathrm{Na}: \mathrm{K}$ ratio while this increase varied with linseed genotypes. The minimum $\mathrm{Na}: \mathrm{K}$ ratio was determined in line 194, followed by lines 193 and 215 . Natarajan et al. (2005) reported that the genotypes with lower $\mathrm{Na}$ K ratio resulted in higher grain yield in rice.

According to the classification for salinity tolerance based on $\mathrm{Na}^{+}$content of seedling, lines 193, 215, and 194 were tolerant and C-90, lines 89, 104, and cv. Sar185 were moderately tolerant, while lines 114,87 , and 209 could be rank as sensitive to salinity (Figure 2). On the basis of Na:K ratio, lines 193, 194, 215, C-90, and 104 could be regarded as tolerant and lines 114 and 89 were moderately tolerant, while line 209 , cv. Sar1-85, and line 87 could be classified as salt-sensitive genotypes (Figure 3). Principal Component and Cluster Analysis based on mean values of germination and seedling characteristics showed that lines 193, 194, and 215 could be grouped as tolerant, and lines 89, 104, C-90, and cv. Sar1-85 were moderately tolerant while lines 114,87 , and 209 could be arranged as salt-sensitive (Figure 4).

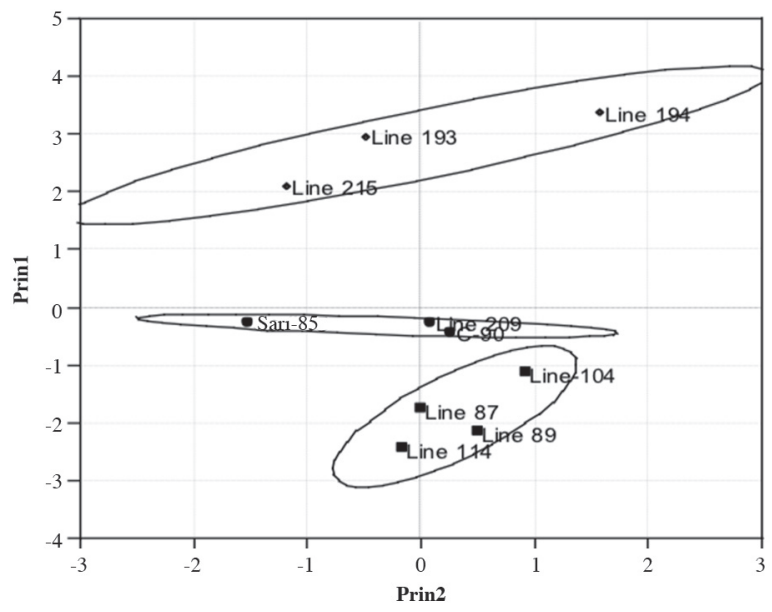

Figure 4. Classification of 10 linseed genotypes subjected to various $\mathrm{NaCl}$ concentrations for salinity tolerance using combination of Principal Component and Cluster Analysis. Prin represents Principal Component Analysis. 


\section{CONCLUSIONS}

Laboratory screening of 10 linseed genotypes for salt tolerance at germination and early seedling growth indicated a large variation among genotypes. Also, there were differences among the linseed genotypes for salt tolerance and three classification methods confirmed that lines 194, 193, and 215 were more tolerant to high salt concentrations than the others while lines 114, 87, and 209 were the susceptible. Combination of Principal Component and Cluster Analysis could be successfully used for classification of the genotypes against salinity. However, further study should be performed to classify linseed for salt tolerance under field conditions to evaluate the possibility of linseed cultivation on salt-contaminated areas.

Clasificación de algunos genotipos de linaza (Linum usitatissimum L.) para tolerancia a salinidad usando germinación, crecimiento de plántulas y contenido de iones. La salinidad reduce germinación, retrasa emergencia, e inhibe el crecimiento de plántulas de lino (Linum usitatissimum L.) mientras algunas variedades son menos afectadas por la salinidad que otras. El objetivo de este estudio fue determinar los efectos de niveles de $\mathrm{NaCl}$ $\left(0,5,10,20\right.$ and $\left.30 \mathrm{dS} \mathrm{m}^{-1}\right)$ en germinación y crecimiento de plántulas de 10 genotipos de lino (líneas 87, 89, 104, $114,193,194,209,215$, C-90 y cv. Sar1-85) y clasificar los genotipos por tolerancia a salinidad usando características de germinación y de plántulas. Se evaluaron porcentaje de germinación, tiempo medio de germinación, longitud de raíces y brotes, peso fresco y seco de plántulas, contenido de $\mathrm{Na}^{+}$y relación $\mathrm{Na}: \mathrm{K}$ de las plántulas. La clasificación de los genotipos de lino por tolerancia a salinidad se hizo de acuerdo a (i) combinación de Análisis de Cluster y Componentes Principales, (ii) contenido de $\mathrm{Na}^{+}$, y (iii) relación Na:K de plántulas. Los resultados muestran que los valores mayores se obtuvieron en las líneas 193, 194, y 215 excepto para tiempo medio de germinación, mientras el porcentaje de germinación no fue adversamente influenciado por $\mathrm{NaCl}$ hasta $20 \mathrm{dS} \mathrm{m}^{-1}$. El crecimiento de plántulas fue inhibido a $20 \mathrm{dS} \mathrm{m}^{-1}$ aunque los genotipos exhibieron variadas respuestas. El contenido de $\mathrm{Na}^{+}$fue elevado por $\mathrm{NaCl}$, pero plántulas de las líneas 194, 193, y 215 tuvieron los menores contenidos de $\mathrm{Na}^{+}$en todos los niveles de $\mathrm{NaCl}$. El análisis de cluster realizado por parámetros múltiples reveló tres grupos para tolerancia a salinidad. Se concluyó que las líneas 193, 194, y 215 eran tolerantes, las líneas 87, 209, C-90, y cv. Sar1-85 fueron moderadamente tolerantes, y las líneas 89,104 , y 114 fueron genotipos sensibles a sal. La clasificación de genotipos por contenido de $\mathrm{Na}^{+}$y relación $\mathrm{Na}: \mathrm{K}$ mostró resultados similares para genotipos tolerantes mientras se detectaron genotipos diferentes para el grupo sensible.

Palabras clave: Linum usitatissimum, $\mathrm{NaCl}$, tolerancia, cluster, acumulación de iones.

\section{LITERATURE CITED}

Akhtar, J., T. Ul-Haq, A. Shahzad, M. Anwar-Ul-Haq, M. Ibrahim, and N. Ashraf. 2003. Classification of different wheat genotypes in salt tolerance categories on the basis of biomass production. International Journal of Agriculture and Biology 5:322-325.

Alian, A., A. Altman, and B. Heuer. 2000. Genotypic difference in salinity and water stress tolerance of fresh market tomato cultivars. Plant Science 152:59-65.

Almansouri, M., J.M. Kinet, and S. Lutts. 2001. Effect of salt and osmotic stresses on germination in durum wheat (Triticum durum Desf.). Plant and Soil 231:243-254.

Ashraf, M., and H. Fatima. 1994. Intra-specific variation for salt tolerance in linseed (Linum usitatissimum L.). Journal of Agronomy and Crop Science 173:193-203.

Ashraf, M., and J.W. O'Leary. 1997. Responses of a salt tolerant and a salt-sensitive line of sunflower varying sodium/calcium ratios in saline sand culture. Journal of Plant Nutrition 20:361-377.

Atak, M., M.D. Kaya, G. Kaya, Y. C1kılı, and C.Y. Ciftci. 2006. Effects of $\mathrm{NaCl}$ on the germination, seedling growth and water uptake of triticale. Turkish Journal of Agriculture and Forestry 30:39-47.

Bassil, E.S., and S.R. Kaffka. 2002. Response of safflower (Carthamus tinctorius L.) to saline soils and irrigation II. Crop response to salinity. Agricultural Water Management 54:81-92.

Berti, M., S. Fischer, R. Wilckens, F. Hevia, and B. Johnson. 2010. Adaptation and genotype $\times$ environment interaction of flaxseed (Linum usitatissimum L.) genotypes in South Central Chile. Chilean Journal of Agricultural Research 70:345-356.

Chandru, R., N.N. Chikkadevaiah, and M.N. Merwade. 1993. Salt tolerance of sunflower hybrids during germination and seedling growth. National Seminar Oilseeds Research and Development in India: Status and Strategies, Hyderabad. 2-5 August. Indian Society of Oilseeds Research, Hyderabad, India.

Couture, S.J., A. DiTommaso, W.L. Asbil, and A.K. Watson. 2004. Influence of seeding depth and seedbed preparation on establishment, growth and yield of fibre flax (Linum usitatissimum L.) in Eastern Canada. Journal of Agronomy and Crop Science 190:184-190.

Diederichsen, A., and L.L. Jones-Flory. 2005. Accelerated aging tests with seeds of 11 flax (Linum usitatissimum) cultivars. Seed Science and Technology 33:419-429.

El-Nagdy, G.A., D.M.A. Nassar, E.A. El-Kady, and G.S.A. ElYamanee. 2010. Response of flax plant (Linum usitatissimum L.) to treatments with mineral and bio-fertilizers from nitrogen and phosphorus. Journal of American Science 6:207-217.

El-Nakhlaway, F.S., and M.A. El-Fawal. 1989. Tolerance of five oil crops to salinity and temperature stresses during germination. Acta Agronomica Hungarica 38:59-65.

Ghorashy, S.R., N. Sionit, and M. Kheradnam. 1972. Salt tolerance of safflower varieties (Carthamus tinctorius L.) during emergence. Agronomy Journal 64:256.

Hakim, M.A., A.S. Juraimi, M. Begum, M.M. Hanafi, M.R. Ismail, and A. Selamat. 2010. Effect of salt stress on germination and early seedling growth of rice (Oryza sativa L.). African Journal of Biotechnology 9:1911-1918.

Hocking, P.J., J.A. Kirkegaard, and J.F. Angus. 1997. Comparison of canola, Indian mustard and linola in two contrasting environments. I. Effects of nitrogen fertilizer on dry matter production, seed yield and seed quality. Field Crops Research 49:2-3.

Hosseinian, F.S., G.G. Rowland, P.R. Bhirud, J.H. Dych, and R.T. Tyler. 2004. Chemical composition and physicochemical and hydrogenation characteristics of high-palmitic acid solin (lowlinolenic acid flaxseed) oil. Journal of the American Oil Chemists' Society $81: 185-188$.

ISTA. 2003. ISTA Handbook on seedling evaluation. $3^{\text {rd }}$ ed. International Seed Testing Association (ISTA), Zurich, Switzerland.

Johnson, H.E., D. Broadhurst, R. Goodacre, and A.R. Smith. 2003. Metabolic fingerprinting of salt-stressed tomatoes. Phytochemistry 62:919-928 
Kacar, B., and A. Inal. 2008. Plant analysis. Nobel Press, Ankara, Turkey.

Katerji, N., J.W. van Hoorn, A. Hamdy, and M. Mastrorilli. 2000. Salt tolerance classification of crops according to soil salinity and to water stress day index. Agricultural Water Management 43:99109.

Kaya, M.D., and S. Day. 2008. Relationship between seed size and $\mathrm{NaCl}$ on germination, seed vigor and early seedling growth of sunflower (Helianthus annuus L.). African Journal of Agricultural Research 3:787-791.

Kaya, M.D., A. Ipek, and A. Ozturk. 2003. Effects of different soil salinity levels on germination and seedling growth of safflower (Carthamus tinctorius L.). Turkish Journal of Agriculture and Forestry 27:221-227.

Kaya, M., G. Kaya, M.D. Kaya, M. Atak, S. Saglam, K.M. Khawar, and C.Y. Ciftci. 2008. Interaction between seed size and $\mathrm{NaCl}$ on germination and early seedling growth of some Turkish cultivars of chickpea (Cicer arietinum L.). Journal of Zhejiang University Science B 9:371-377.

Kaya, M.D., G. Okcu, M. Atak, Y. Cıkılı, and O. Kolsarıcı. 2006. Seed treatments to overcome salt and drought stress during germination in sunflower (Helianthus annuus L.). European Journal of Agronomy 24:291-295.

Khajeh-Hosseini, M., A.A. Powell, and I.J. Bingham. 2003. The interaction between salinity stress and seed vigour during germination of soybean seeds. Seed Science and Technology 31:715-725.

Kurt, O., and D. Bozkurt. 2006. Effect of temperature and photoperiod on seedling emergence of flax (Linum usitatissimum L.). Journal of Agronomy 5:541-545.

Mer, R.K., P.K. Prajith, D.H. Pandya, and A.N. Pandey. 2000. Effect of salts on germination of seeds and growth of young plants of Hordeum vulgare, Triticum aestivum, Cicer arietinum and Brassica juncea. Journal of Agronomy and Crop Science 185:209-217.

Muhammad, Z., and F. Hussain. 2010. Effect of $\mathrm{NaCl}$ salinity on the germination and seedling growth of some medicinal plants. Pakistan Journal of Botany 42:889-897.

Munns, R. 2002. Comparative physiology of salt and water stress Plant, Cell and Environment 25:239-250.

Munns, R., R.A. James, and A. Lauchi. 2006. Approaches to increasing the salt tolerance of wheat and other cereals. Journal of Experimental Botany 57:1025-1043.

Natarajan, S.K., M. Ganapathy, S. Krishnakumar, R. Dhanalakshmi, and B.B. Saliha. 2005. Grouping of rice genotypes for salinity tolerance based upon grain yield and $\mathrm{Na}: \mathrm{K}$ ratio under coastal environment. Research Journal of Agriculture and Biological Sciences 1:162-165.

Naureen, G., and F.N. Naqvi. 2010. Salt tolerance classification in wheat genotypes using reducing sugar accumulation and growth characteristics. Emirates Journal of Food and Agriculture 22:308317

O'Connor, B.J., and L.V. Gusta. 1994. Effect of low temperature and seeding depth on the germination and emergence of seven flax (Linum usitatissimum L.) cultivars. Canadian Journal of Plant Science 74:247-253

Pessarakli, M. 1999. Handbook of plant and crop stress. $1254 \mathrm{p}$ Marcel Dekker Inc., New York, USA.

Saboora, A., and K. Kiarostami. 2006. Salinity $(\mathrm{NaCl})$ tolerance of wheat genotypes at germination and early seedling growth. Pakistan Journal of Biological Science 9:2009-2021.

Saeidi, G., and G.G. Rowland. 1997. The inheritance of variegated seed color and palmitic acid in flax. Journal of Heredity 88:466468.

Sankari, H.S. 2000. Linseed (Linum usitatissimum L.) cultivars and breeding lines as stem biomass producers. Journal of Agronomy and Crop Sciences 184:225-231.

Soltani, A., S. Galeshi, E. Zeinali, and N. Latifi. 2002. Germination, seed reserve utilization and seedling growth of chickpea as affected by salinity and seed size. Seed Science and Technology 30:51-60 